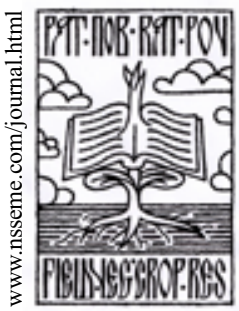

\title{
Microbiological Properties of Rankers in the Region of Western Serbia
}

\author{
Nataša Rasulić • Dušica Delić • Olivera Stajković-Srbinović • \\ Đorđe Kuzmanović • Dragana Jošić
}

\author{
received: 29 November 2011, accepted: 4 April 2012 \\ (c) 2012 IFVC \\ doi: $10.5937 /$ ratpov $49-1227$
}

\begin{abstract}
Summary: Ranker, or humus-silicate soil, is one of the most represented types of soil in the hillymountainous region of Western Serbia. Aiming to determine biogenity of such type of soil in Western Serbia, representation of the total microflora, fungi, actinomycetes, ammonifiers, azotobacter and oligonitrophiles has been examined as well as dehydrogenase activity of this type of soil. The samples were taken from soils used in three different ways: plough-fields, orchards and forests. The standard microbiological methods of introducing in certain decimal dilutions on the appropriate nutritive medium were used. The obtained results showed small biota of the tested soil. No correlation between a number of the stated groups of microorganisms and the way of using the soil was found. The highest dehydrogenase activity was shown by forests. The number of azotobacter, as soil fertility indicator, was small in the forest regions.
\end{abstract}

Key words: azotobacter, biogenity, dehydrogenase, forests, microorganisms, orchards, rankers, soils

\section{Introduction}

As the most significant biological component of soil, microorganisms actively participate by enzymatic systems in processes of decomposition of organic and non-organic substance, synthesis of humus and making available plant nutrients (Milošević et al. 2003). Microorganisms participate in $60-90 \%$ of overall metabolic activities in soil, and are significant for fertility improvement and maintenance (Lee 1994). Certain groups and types of microorganisms in various types of soil can serve as an indicator of soil biogenity and fertility (Milošević et al. 1997). The number of microorganisms in soil also depends on the presence and nature of organic matter, mode of procession, fertilizing, vegetal cover and other abiotic factors such as $\mathrm{pH}$, temperature, moisture of soil, presence of heavy metals, pesticides and other harmful substances (Vojinović et al. 1982, Miličić \& Vojinović 1991, Belanović et al. 2004). The number of microorganisms in soil is characterized by huge dynamics in a relative short period of time, so that their number can be changed as consequence of the temperature dynamics and the soil moisture as the vegetal cover (Miličić et al. 2007).

N. Rasulić* • D. Delić • O. Stajković-Srbinović • Đ. Kuzmanović • D. Jošić

Institute of Soil Science, Teodora Drajzera 7, 11000 Belgrade, Serbia e-mail: nrasulic@yahoo.com
One of the most spread types of soil are rankers, i.e. black soil on the silicate rocks (Živković 1965) and comprise soils in the hilly-mountainous belt at the sea height level of 150-2000 m (Antić et al. 1990). Biological activity of soil was examined for assessment of its biogenity depending on mode of utilization (ploughing soil, orchards and forests). Representativeness of the most important physiological microorganisms groups and their dehydrogenase activity was determined in that aim.

\section{Materials and Methods}

Soil samples from the chosen locations were taken for the microbiological analysis aseptically from the depth of $0-25 \mathrm{~cm}$. The basic parameters for assessment of the soil biogenity were: total microflora, total number of fungi, actinomycetes, ammonifiers, azotobacter, ologonitrophiles and the dehydrogenase activity of soil. The number of microorganisms was determined according to the dilution method on the appropriate nutritive medium by using the decimal dilutions $\left(10^{-1}-10^{-8}\right)$, (Pochon \& Tardieux 1962). The total number of bacteria was determined on the agarised soil extract, fungi on the Chapek medium, actinomycetes on the synthetic agar with sacharose

Supported by Ministry of Education and Science of the Republic of Serbia, Project No. TR 46007. 
according to Krasilynikov, ammonifiers on the liquid medium with asparagines as the source of nitrogen, Azotobacter sp. on the liquid medium with mannitol and oligonitrophiles on the medium according to Fyodorov. The dehydrogenase activity of soils was determined as per the Lenhard method (1956) modified as per Thalman (1968), based on the measuring of trifenil formazan extinction (TPF) developed from reduction of 2,3,5- trifenil tetrazolium chloride. In addition to numerous physiological microorganisms groups, as well as the dehydrogenase activity, $\mathrm{pH}$ value of the tested samples was done indicating the acid reaction having unfavourable impact to the microbiological activity of the tested soil.

\section{Results and Discussion}

The number of microorganisms and dehydrogenase activity indicating the tested soil biogenity level (Milošević et al. 1992) are shown in Table 1. The total number of microorganisms in the tested ploughing soils varied from 2.33 to 44.50 $10^{6} \mathrm{~g}^{-1}$, in orchards from 3.50 to $36.5010^{6} \mathrm{~g}^{-1}$ and in the forest soil samples from 0.67 to $127.3310^{6}$ $\mathrm{g}^{-1}$. The highest total number of microorganisms was found in the forest soil (sample No. 4) and it significantly stood apart by the total microflora from the other tested samples. Regarding this parameter, there were no huge differences among the tested samples indicating that the total number of microorganisms did not depend on a mode of the soil utilization.

Number of actinomycetes in the tested ploughing soil varied from 1.67 to $13.5010^{4} \mathrm{~g}^{-1}$, in orchards 2.33 to $28.0010^{4} \mathrm{~g}^{-1}$ and in the forest soils ranging from 0 to $20.0010^{4} \mathrm{~g}^{-1}$. The highest unevenness of a number of actinomycetes was found in samples from orchards excelling by the highest number of these important humificators (sample No. 3).

Fungi have shown uneven presence in the tested samples meaning that their numerousness did not depend on a mode of the soil utilization. Their number ranged from 3.00 to $65.0010^{4}$ $\mathrm{g}^{-1}$, in orchards 1.00 to $45.3310^{4} \mathrm{~g}^{-1}$ and their numerousness mostly varied in the forest soils samples ranging from 0 to $81.3310^{4} \mathrm{~g}^{-1}$ concurrently representing the highest number of these significant decomposers of the organic substances in soil.

Ammonifiers, as users of the organic nitrogen and protein degraders, are one of the most represented microorganisms groups in soil (Bogdanović 1990). Their numerousness in the soil type chernozem (black earth) can reach the values of $10^{7}-10^{9} \mathrm{~g}^{-1}$, (Govedarica et al. 2000). Their number in the tested ploughing soil varied from 3.00 to $25.0010^{5} \mathrm{~g}^{-1}$, in orchards from 0.90 to $110.0010^{5} \mathrm{~g}^{-1}$ where the highest number of this physiological group of microorganisms was recorded (sample No. 3). The samples of the forest soils have shown the least presence of ammonifiers varying from 0 to $25.0010^{4} \mathrm{~g}^{-1}$.

Azotobacter sp., as indicator of fertile soil and the strongest associative fixation factor of the atmospheric nitrogen, showed low presence in the tested samples of the ploughing soil and orchards, and full absence in the forest soils at six locations. A location of the orchard was an exception (sample No. 4) where number of $250 \mathrm{~g}^{-1}$ was found. According to the references, azotobacter in the ploughing soil can reach number of $10^{3} \mathrm{~g}^{-1}$ (Vojinović et al. 1982, Govedarica et al. 1996, Jarak et al. 2003), leading to the conclusion that the rankers, as a type of soil, do not render optimal conditions for activity of this nitrogen-fixation factor.

Oligonitrophiles, as fixation factors of the atmospheric nitrogen for meeting their own needs and suppliers of plants with accessible forms of nitrogen (Bogdanović 1990), represented the dominant physiological group of microorganisms in the tested samples thus indicating the unfavourable nitrogenous regime of rankers as a type of soil. Their presence did not depend on a mode of utilization and their numerousness ranged from 0.67 to $164.0010^{5} \mathrm{~g}^{-1}$. In this example, the location of orchard (sample No. 10) showed the highest number.

Establishingactivities of the enzyme participating in mineralization of the organic substance in soil is an indicator of the soil biological activity (Najdenovska et al. 2004). One of these enzymes is oxydoreducing enzyme of dehydrogenase. Dehydrogenase activity may be considered a good measure for microbial oxidative activity in soil. Ross (1970) stated that dehydrogenase activity appeared to be more dependent on the metabolic state of the soil and on the biological activity of the microbial population than on any present free enzyme. Bolton et al. (1984) were the first to notice the dependency of dehydrogenase activity on fertilization and cropping practices. Dehydrogenase activity of the tested ploughing soil ranged from 2.98 to $62.07 \mu \mathrm{g} \mathrm{TPF} / \mathrm{g}$, orchards from 7.22 to $68.05 \mu \mathrm{g} \mathrm{TPF} / \mathrm{g}$, forest locations from 3.43 to $60.00 \mu \mathrm{g} \mathrm{TPF} / \mathrm{g}$. Also in this case, the highest activity was shown by orchard locations. Nevertheless, the dehydrogenase activity of the tested ranker samples is significantly lower than the dehydrogenase activity of alluvium and other types of soil (Jarak et al. 2003). Correlation of the dehydrogenase activity of the tested samples with the total number of microorganisms was not found. 


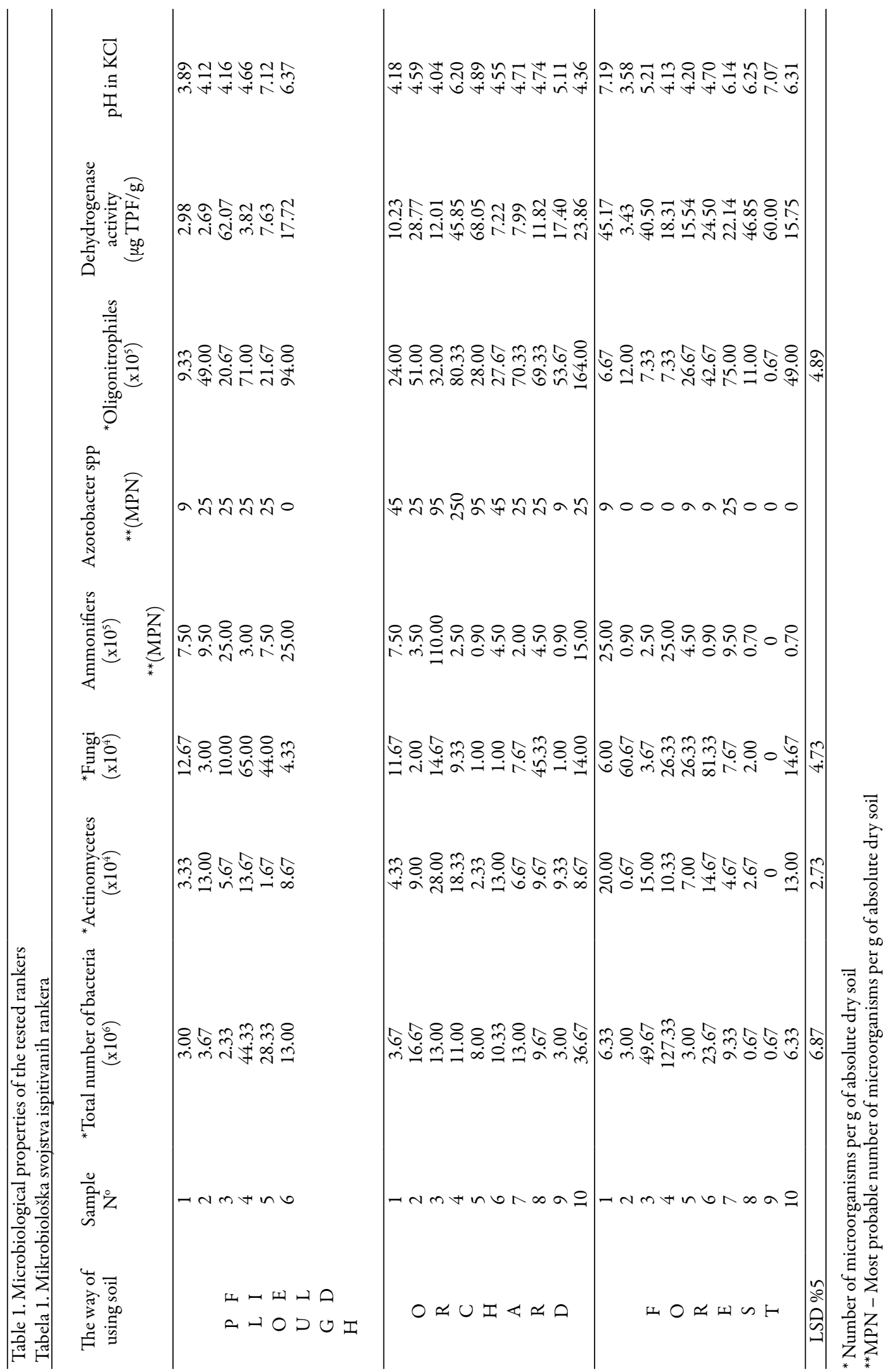




\section{Conclusion}

Rankers at the location of western Serbia have not shown biogenity which can be attributed mainly to unfavourable chemical properties of this type of soil and also to the acid reaction. The number of the total microflora and actinomycetes, ammonifiers, azotobacter and oligonitrophiles did not depend on a mode of the soil utilization. As expected, fungi were numerous in the forest locations. Presence of Azotobacter at the same location was the least, i.e. its presence was not recorded with a higher number of the samples. Dehydrogenase activity was at the highest level at the forest locations.

\section{References}

Antić M, Jović N, Avdalović V (1990): Pedologija, Naučna knjiga, Beograd

Bogdanović V (1990): Zastupljenost mikroorganizama u deponiji pepela. Zemljište i biljka 39: 139-145

Bolton Jr LF, Elliott RI Papendick, Bezdicek D. F. (1984): Soil Microbial biomass and and selected soil enzyme activities: Effect of fertilization and cropping practices. Soil Biol. Biochem. $17: 297-302$

Govedarica M, Milošević N, Jarak M, Ubavić M, Radanović Z (1996): The effect of farthworm and green manure on the microbiological activity in wheat. Zemljište i biljka 45: 121-126

Govedarica M, Milošević N, Jarak M, Đurić S, Milošević D, Konstatinović B (2000): Uticaj herbicida na mikrobiološku aktivnost u zemljištu pod usevom pšenice. EKO-konferencija 2000. Zdravstveno bezbedna hrana, Tematski zbornik, II, 25-30

Jarak M, Belić M, Govedarica M, Milošević N, Đurić S (2003): Effect of phosphogypsum and peat on microbiological and chemical properties of arenosol. Zemljište i biljka 52: 1-6

Lee KE (1994): The functional significance of biodiversity in soils. 15th World Congress of Soil Science, Acapulco, Mexico, 10-16. 07. 1994. 4a: 168-182

Milošević N, Redžepović S, Govedarica M, Jarak M (1992): Activity of dehydrogenase and cellulolytic enzymes in some hydromorphic soils. Zemljište i biljka 41: 159-170

Milošević N, Ubavić M, Čuvardić M, Vojin S (1997): Mikrobi zemljišta: značaj i mogućnosti. Unapređenje, korišćenje i očuvanje zemljišta. Jugoslovensko društvo za proučavanje zemljišta, Novi Sad, 389-397

Milošević N, Ubavić M, Čuvardić M, Vojin S (2003): Mikrobiznačajno svojstvo za karakterizaciju plodnosti poljoprivrednog zemljišta. Agroznanje 4: 81-88

Najdenovska O, Đorđević S, Mitkova T (2004): Overall heavy metal content and biochemical activity in the soil planted with potato. Zemljište i biljka 53: 191-196

Pochon et Tardieux (1962): Tehnikues danalise en microbiologique du Soil edit de la tourel, Paris

Ross DJ (1970): Effects of storage on dehydrogenase activity of soils. Soil Biology \& Biochemistry 12: 375-383

Thalmann A (1968): Zur Methodil des Bestimmung der Dehidrogenase Activat in Boden Mittles Tripheyltetrazoliumhlorid TTC, London Forch 21: 249-258

Vojinović Ž, Milošević R, Peno M, Veselinović N, Miličić B (1982): Stanje mikrobiocenoza u zemljištima oštećenim poplavnim vodama Timoka. Zemljište i biljka 31: 307-313

Živković M (1965): Prilog proučavanju geneze humusno silikatnih zemljišta Srbije. Zemljište i biljka 14: 172-179

\title{
Mikrobiološke osobine rankera na području zapadne Srbije
}

\author{
Nataša Rasulić • Dušica Delić • Olivera Stajković-Srbinović • \\ Đorđe Kuzmanović • Dragana Jošić
}

Izvod: Jedan od najzastupljenijih tipova zemljišta u brdsko-planinskom području zapadne Srbije je ranker ili humusnosilikatno zemljište. U cilju utvrđivanja biogenosti ovog tipa zemljišta u zapadnoj Srbiji, ispitana je zastupljenost ukupne mikroflore, gljivica, aktinomiceta, amonifikatora, azotobaktera i oligonitrofila, kao i dehidrogenazna aktivnost navedenog tipa zemljišsta. Uzorci su uzeti iz zemljišsta korišćenih na tri različita načina, a to su oranice, voćnjaci i šume. Korišćene su standardne mikrobiološke metode zasejavanja određenog decimalnog razređenja na odgovarajuće hranljive podloge. Dobijeni rezultati su pokazali malu biogenost ispitivanog zemljišta, što bi moglo biti posledica nepovoljne reakcije ovog tipa zemljišta, odnosno niske $\mathrm{pH}$ vrednosti. Nije ustanovljena korelacija između broja navedenih grupa mikroorganizama i načina korišćenja zemljišta. Najveću dehidrogenaznu aktivnost su pokazali voćnjaci. Utvrđena je mala zastupljenost azotobaktera, kao indikatora plodnosti zemljišta, u lokalitetima pod šumom.

Ključne reči: azotobacter, biogenost, dehidrogenaza, mikroorganizmi, rankeri, šume, voćnjaci, zemljišta 